1 Original Investigation

2 Categorizing ten sports according to bone and soft tissue profiles in adolescents

3 Ricardo Ribeiro Agostinete ${ }^{1 *}$, Romulo Araújo Fernandes ${ }^{1}$, Pedro Henrique Narciso ${ }^{1}$, Santiago

4 Maillane-Vanegas ${ }^{1}$, André Oliveira Werneck ${ }^{1}$, Dimitris Vlachopoulos ${ }^{2}$.

6 1- Laboratory of InVestigation in Exercise (LIVE), Department of Physical Education,

7 Sao Paulo State University (UNESP), Presidente Prudente, Brazil.

8

9 2- Children's Health and Exercise Research Centre, Sport and Health Sciences,

10 University of Exeter, United Kingdom.

11

$12 *$ Corresponding author: Ricardo Ribeiro Agostinete (ricardo.agostinete@unesp.br).

13 Laboratory of InVestigation in Exercise (LIVE), Departamento f Physical Education, São

14 Paulo State University (UNESP), 305 Roberto Simonsen - Presidente Prudente, São Paulo,

15 Brazil. 19060 -900

16

17

18

19

20

21 


\section{Categorizing ten sports according to bone and soft tissue profiles in adolescents}

\section{Abstract}

3 Purpose: Considering the different loading and training characteristics of the sports practiced

4 during growth, it is important to specify and categorize the bone and soft tissue adaptations in

5 adolescent athletes. This study aimed to categorize ten different loading sports and a non-sport

6 group and identify the differences in bone density and soft tissues. Methods: The sample

7 included 625 adolescents (10 to 17 years of age) of ten sports (soccer, basketball, volleyball,

8 track \& field, judo, karate, kung-fu, gymnastics, baseball and swimming) and a non-sport

9 group. Dual energy X-ray absorptiometry assessed areal bone mineral density (aBMD), bone

10 mineral apparent density (BMAD) and soft tissues (lean soft tissue and fat mass). The results

11 were adjusted for sex, peak height velocity (PHV) status, lean soft tissue, fat mass and weekly

12 training volume. Results: The comparisons among groups showed that soccer had the highest

13 whole body aBMD (mean \pm SEM: $\left.1.082 \mathrm{~g} / \mathrm{cm}^{2} \pm 0.007\right)$ and lower limbs aBMD (1.302g/cm ${ }^{2}$

$14 \pm 0.010)$. Gymnastics presented the highest upper limbs $\left(0.868 \mathrm{~g} / \mathrm{cm}^{2} \pm 0.012\right)$ and whole body

BMAD $\left(0.094 \mathrm{~g} / \mathrm{cm}^{2} \pm 0.001\right)$. Swimming presented the lowest aBMD values in all skeletal sites (except at the upper limbs) and whole body BMAD. The soft tissue comparisons showed that soccer had the highest lean soft tissue $(43.8 \mathrm{~kg} \pm 0.7)$. The lowest fat mass was found in gymnastics (8.04 $\mathrm{kg} \pm 1.0)$. Conclusion: The present study investigated and categorised for the first time ten different sports according to bone density and soft tissue profiles. Soccer and gymnastics sport groups found to have the highest bone density in most body segments and both sports were among the groups with the lowest fat mass.

Key Words: ADOLESCENCE, BONE MINERAL DENSITY, EXERCISE, FAT MASS, 


\section{Introduction}

Adolescence is a crucial period for accumulation of bone mass with evidence indicating that $33 \%$ to $43 \%$ of the total bone mineral content (BMC) in adulthood is accumulated during the years surrounding peak height velocity (PHV), depending on the skeletal site (1). These circumpubertal years ( -2 to +2 years from age of PHV) are particularly important for the assessment of somatic maturation (1). Exercise and dietary intake during adolescence play an important role on the accumulation of bone mass during growth $(2,3)$. Also, exercise has the potential to optimise bone health during growth by achieving the full potential of peak bone mass and by reducing the risk of osteoporosis later in life (4), leading to substantial economic and social gains (5).

Participation in sports during growth can have several positive effects on physiological, metabolic and musculoskeletal health outcomes $(6,7)$. Evidence indicates that the type and characteristics of the sports practiced during growth can have different adaptations on bone mass and the highest benefits are observed in those who participate in weight-bearing sports $(3,8-10)$. During weight-bearing sport participation the mechanical forces applied on the bone matrix directly (ground reaction forces) or indirectly (via the muscle contraction) (10). The muscle contractions and the osteogenic stimulus produced from high external forces during exercise (ground reaction forces), such as jumps, sprints, acceleration and deceleration are responsible for the adaptations in in bone mineral accrual (10). Most studies in the literature focusing on sports participation and bone health during growth are comparing a specific sport modality or limited number of sports with a control group $(8,11)$. Currently, there are a considerable range of sports with few data available about its osteogenic properties, even though they are widely practiced for children and adolescents worldwide, such as martial arts. This background requires a comprehensive investigation about the site-specific skeletal adaptations of the growing skeleton. However, there is no evidence regarding the bone 
1 adaptations of the different loading sports practiced during growth and how these are 2 categorized according to the skeletal adaptations.

Dual-energy X-ray absorptiometry (DXA) is the clinically relevant method to use when assessing bone health during growth, but differences in the size of the children or adolescents can affect the interpretation of areal bone mineral density (aBMD). This is mainly because aBMD is analysed in $\mathrm{g} / \mathrm{cm} 2$ and does not consider the bone volume $\left(\mathrm{cm}^{3}\right)$. Considering that adolescents have evident size differences according to the sports practiced due to the natural selection of each sport modality, the comparisons of aBMD can be affected (12). Therefore, it is important to consider and adjust further for the size differences when comparing BMD of children and adolescents. A more thorough investigation can be provided by using bone mineral apparent density (BMAD) which reduces the confounding role of skeletal size and provide an estimation of volumetric bone density proportional to the true bone volume (13). Previous studies have considered the use of this technique (BMAD) to analyse the impact of some sports, such as gymnastics (14) and cycling (15) on bone density of lumbar spine, femoral neck and whole body in adolescents. However, the BMAD has not yet been used in comparisons of bone health among different loading sports within the same study.

In addition to bone differences, previous evidence indicates that depending on the sport practiced, the soft tissues, specifically lean and fat mass, differ according to the movementspecific characteristics of the sport practiced (16). Wilkinson et al (17) found that adolescent swimmers had higher lean mass when compared with footballers, cyclists and a control group. Additionally, all sports groups (swimmers, footballers and cyclists) had lower fat mass than an active age-matched control group. Understanding the relations of different sports on lean and fat mass will allow the sports professionals and researchers to identify the body composition status of young athletes and design effective interventions to improve it. However, there is a lack of comprehensive evidence comparing the soft tissue of a large number of sports practiced 
1 during adolescence. Considering that the majority of children and adolescents are involved in

2 different types of sports during this period of life (mainly in adolescence when sports

3 participation is the main manifestation of physical exercise), it is crucial to identify their

4 specific impact on bone health and soft tissues during this important period of life.

Thus, the objective of this study was to categorize adolescent athletes from ten different

6 loading sports (soccer, basketball, volleyball, tennis, track \& field, judo, karate, kung fu,

7 gymnastics, baseball and swimming) and a non-sport group according to bone and soft tissues

8 profiles as well as to quantify the differences in bone density and soft tissues by controlling for

9 important confounders.

\section{Methods}

\section{Population}

The data of this cross-sectional study were collected as part of two studies from the

13 Laboratory of InVestigation in Exercise (LIVE) that was conducted in the city of Presidente

14 Prudente, São Paulo-Brazil from October 2013 to May 2018. After authorization of the local

15 authorities, researchers contacted and invited the non-sport group adolescents by inviting

16 schools of the Secretary of Education and in one Philanthropic Institution. The sport groups

17 were recruited from sport clubs (public and private) of the metropolitan area of Presidente

18 Prudente. The initial number of adolescents recruited was 678, and after exclusions (see

19 inclusion criteria), the sample was composed of 625 adolescents (184 females) with mean age

20 of $14.1(13.9$ to 14.2$)$ years.

21 The inclusion criteria were: 1) chronological age between 10 and 17 years of age; 2) a

22 minimum of 6 months of participation in the specific sport (sport groups); 3) minimum engagement of 3 or more hours per week (sport groups). The exclusion criteria were: 1) currently taking medication that could affect bone metabolism; 2) organized involvement in 
1 other sports on top of the specialized sport (sport groups); 3) organized involvement in sports

2 (presence of coach, training routine, competitions) (non-sport group).

The sample size estimation was performed using an equation previous used in other studies $(9,18,19)$, a bilateral student $t$ test considering the difference between two dependent means of cyclists ( 1.133 units $[\mathrm{SD}=0.217]$ in reference group and 1.002 units $[\mathrm{SD}=0.093$ ] in experimental group) of whole-body BMD (15). Taking into account a power of $90 \%$ and an alpha of 5\%, the sample size was estimated as a minimum of 9 adolescents per group.

The sport group comprised of 453 adolescents of 10 different sports: judo $(n=54$ [females $n=18$ ]), karate $(n=41$ [females $n=21])$, kung fu $(n=39$ [females $n=10])$, swimming $(n=67$ [females $n=22])$, basketball $(n=55$ males $)$, soccer $(n=100$ males $)$, volleyball $(n=32$ [females $n=30])$, track and field $(n=27$ [females $n=11])$, baseball $(n=22$ [females $n=1])$ and artistic gymnastics ( $\mathrm{n}=16$ females), and the non-sport group comprised of 172 adolescents (55 females).

To participate in the study, adolescents were required to provide informed consent forms signed by a parent or guardian. The Ethical Board of the Sao Paulo State University (UNESP) approved the investigation (Process number 02891112.6.0000.5402) and all procedures performed in this study were conducted in accordance with the 1964 Declaration of Helsinki for human studies by the World Medical Association.

\section{Anthropometry}

Stature was measured using a stadiometer (Sanny, model American Medical of the Brazil Ltda, Brazil, accurate to $0.1 \mathrm{~cm}$ ). The body mass was measured using an electronic scale (Filizzola PL 150, model Filizzola Ltda, Brazil with a precision of $0.1 \mathrm{~kg}$ ). All measures were assessed using standardized techniques by a single trained researcher. The technical errors of measurement were $0.04 \%$ and $0.11 \%$ for body mass, height, respectively. 


\section{Somatic Maturation}

Stature measurements and chronological age were used to calculate the maturity offset

3 years from age PHV using equation proposed by Moore et al. (20). This is a somatic biological

4 maturity indicator and reflects the maximum growth velocity during adolescence and the

5 coefficient of determination has been reported $\left(\mathrm{r}^{2}=0.90, \mathrm{SE}=0.5\right)(20)$. Lastly, aiming to

6 decrease the bias of estimation of PHV (21) mainly in samples with large age range (outside

7 the optimal band of estimation [1 year after/before the peak]), the adolescents were divided

8 into three categories: 1) Pre-PHV (maturity offset $<-1$ ); 2) At-PHV (maturity offset $\geq-1$ and

$9 \leq 1$ ) and 3) Post-PHV (maturity offset $>1$ ). These categories were used as a somatic maturation variable of the sample and considered as an adjustment variable in the analysis.

\section{Volume and Frequency of Training}

The athletes and coaches provided information about the time of training per day (minutes trained daily) and frequency of training per week (number of days trained in a week). These variables were used to calculate the weekly training volume, following the equation: time of training per day $\mathrm{x}$ frequency of training per week. Training volume is a widely used variable in studies involving sports training characteristics and able to affect the accumulation of bone mineral density in adolescents (22).

\section{Bone Densitometry and Soft Tissue Assessment}

A whole body DXA scan (Lunar DPX-NT; General Electric Healthcare, Little

Chalfont, Buckinghamshire, UK) was used to assess aBMD $\left(\mathrm{g} / \mathrm{cm}^{2}\right)$, lean soft tissue $(\mathrm{kg})$ and fat mass $(\mathrm{kg})$ of whole body at the university laboratory in a temperature-controlled room by using a GE Medical System Lunar software (version 4.7). A trained researcher performed all scan and tested the scanner quality before the first exam of each day. The coefficient of variation for this device was $0.66 \%$ (in whole body aBMD analysis, $n=30$ participants not involved in this study), setting the lines (rois) in the extremities (upper limbs, lower limbs and 
1 spine) as requested for the General Electric Healthcare company and stated in previous studies

2 (8) realized by a trained researcher. The scans were performed using a standardized protocol

3 with the participants remaining in the supine position and wearing only light clothing, without

4 shoes. Regional analysis for aBMD of upper limbs, lower limbs, spine and whole body (less

5 head) occurred off-line after the scans took place.

6 The BMAD $\left(\mathrm{g} / \mathrm{cm}^{3}\right)$ is an approach to estimate the volumetric BMD and remove the

7 size differences. It can be calculated by dividing BMC by the three-dimensional bone volume

8 derived from its two-dimensional projected bone area (BA) and body height as proposed by

$9 \quad$ Katzman et al (13): $\mathrm{BMAD}_{\mathrm{TB}}=\mathrm{BMC} /\left(\right.$ total body $\mathrm{BA}^{2} /$ body height).

\section{Statistical analysis}

11 All anthropometric characteristics, bone and soft tissue parameters were expressed as 12 mean values, standard deviation (SD) and 95\% confidence intervals (95\%CI). The data 13 normality was tested using the Shapiro-Wilk test. The comparisons of dependent variables 14 among groups were performed by using Generalized Estimating Equation Model (GEE) and

15 Bonferroni post-hoc test. All covariates were selected after checking for multicollinearity and 16 by including possible mediators of bone density based on previous evidence (22-24). 17 Specifically, when comparing bone density variables, the models were adjusted for sex, PHV status, lean soft tissue, fat mass and weekly training volume. To quantify the differences the results were presented by using percentage of difference. The data were analysed using the SPSS software (version 24.0), and the level of statistical significance was set at a palue less 21 than 0.05 . 


\section{$1 \quad$ Results}

Table 1 shows the descriptive characteristics of each group and Table 2 shows the bone variables by sports modalities without adjustments. The adjusted comparisons of dependent variables are presented in Figure 1, Figure 2 and Figure 3. The results of these comparisons are presented hierarchically (from highest to lowest) in figures to facilitate a practical categorization and visualization.

At whole body aBMD, the highest value was observed in soccer $\left(1.082 \mathrm{~g} / \mathrm{cm}^{2}\right)$ and lowest in swimming $\left(0.959 \mathrm{~g} / \mathrm{cm}^{2}\right)$. The swimmers had significantly lower whole-body aBMD compared to all groups (-4.9\% to $-11.3 \%)$. Kung fu presented significant lower whole-body aBMD compared with soccer (-6.7\%) and judo (-4.3\%). Baseball, basketball, karate and nonsport group had significant lower values at whole-body aBMD compared with soccer $(-3.9 \%$ to $-6.5 \%)$ (Figure 1, panel A). Spine aBMD in the judo group was the highest $\left(1.052 \mathrm{~g} / \mathrm{cm}^{2}\right)$, while the swimming group had the lowest spine aBMD $\left(0.971 \mathrm{~g} / \mathrm{cm}^{2}\right)$. In comparisons among groups, the swimming group had significantly lower spine aBMD than judo (-7.7\%), volleyball $(-7.3 \%)$ and soccer $(-5.8 \%)$ (Figure 1, panel B).

At lower limbs aBMD soccer $\left(1.302 \mathrm{~g} / \mathrm{cm}^{2}\right)$ and swimming $\left(1.129 \mathrm{~g} / \mathrm{cm}^{2}\right)$ were the sports with highest and lowest aBMD respectively. Swimmers had significantly lower limbs aBMD compared to all groups (-5.4\% to $-13.3 \%)$. Baseball, kung fu, basketball, non-sport group, karate, judo and volleyball had significant lower limbs aBMD compared with soccer ($4.2 \%$ to $-8.4 \%$ ) (Figure 1, panel C). At the upper limbs aBMD, the highest value was observed in gymnastics group $\left(0.868 \mathrm{~g} / \mathrm{cm}^{2}\right)$ while the lowest upper limbs aBMD value was found in basketball group $\left(0.750 \mathrm{~g} / \mathrm{cm}^{2}\right)$. In the comparisons among the groups, basketball had significantly lower upper limbs aBMD than gymnastics (-13.6\%), judo (-12.1\%), baseball ($6.9 \%)$ and track \& field (-6.5\%). Swimming, kung fu and karate had significantly lower upper limbs aBMD than gymnastics $(-9.5 \%$ to $-10.3 \%)$ and judo $(-8.0 \%$ to $-8.8 \%)$. Soccer, track \& 
1 field, volleyball, non-sport and baseball presented significantly lower upper limbs aBMD 2 compared to gymnastics (-7.2\% to -8.8\%) (Figure 1, panel D). value was observed in gymnastics group $\left(0.094 \mathrm{~g} / \mathrm{cm}^{3}\right)$ and the lowest BMAD value was found in the swimming group $\left(0.085 \mathrm{~g} / \mathrm{cm}^{3}\right)$. Swimmers had significantly lower whole-body BMAD compared to gymnastics $(-10.0 \%)$, track \& field $(-9.0 \%)$, soccer $(-8.9 \%)$, karate $(-5.8 \%)$, volleyball (-5.5\%), judo (-5.4\%), non-sport (-5.4\%) and basketball (-4.5\%) groups. Baseball also had significantly lower whole-body BMAD than gymnastics (-7.4\%), track \& field ($6.3 \%)$ and soccer $(-6.3 \%)$. Kung fu had significantly lower whole-body BMAD than gymnastics $(-6.5 \%)$ and soccer $(-5.4 \%)$. Basketball also had significantly lower whole-body BMAD than gymnastics (-5.8\%).

The soft tissues result showed that baseball had the highest value of fat mass $(19.8 \mathrm{~kg})$, while gymnastics group had the lowest fat mass $(8.0 \mathrm{~kg})$. Gymnastics group had significantly lower fat mass compared to baseball (-59.4\%), kung fu (-49.0\%), volleyball (-47.1\%), judo ($44.8 \%)$ and swimming (-41.4\%) groups. Soccer also presented significantly lower fat mass compared to baseball (-59.3\%), kung fu (-48.9\%), volleyball (-46.9\%), judo (-44.5\%), swimming (-41.3\%), basketball $(-38.7 \%)$ and karate $(-32.0 \%)$. Lastly, track field had significantly lower fat mass than baseball (-59.0\%), kung fu (-48.5\%), volleyball (-46.6\%), judo (-44.1\%), swimming (-48.8\%) and basketball (-38.3\%) (Figure 3, panel A). The lean soft tissue was the highest at the soccer group (43.8 kg), while baseball group had the lowest lean mass $(37.1 \mathrm{~kg})$. The comparisons among groups showed that baseball, volleyball and karate had significantly lower lean soft tissue than soccer $(-11.2 \%$ to $-15.3 \%)$, track \& field ($11.2 \%$ to $-15.3 \%)$ and basketball $(-8.7 \%$ to $-12.9 \%)$, while non-sport, kung fu, judo and swimming groups had significantly lower lean soft tissue than soccer $(-7.1 \%$ to $-11.2 \%)$ 


\section{Discussion}

This study analysed the aBMD, BMAD, lean soft tissue and fat mass of adolescents of ten different sports and categorised the sports according to the bone and soft tissue profiles. The present study included sports that have not previously investigated for these outcomes and by adjusting for potential covariates. The main findings showed that the soccer and gymnastics groups had the highest aBMD and BMAD values at most skeletal sites. In contrast, the swimming group had the lowest aBMD values at most skeletal sites. The main findings of the soft tissue profiles showed that soccer had the highest lean soft tissue while gymnastics had the lowest fat mass.

Whole Body aBMD and BMAD

Regarding aBMD values of whole body, the greatest differences observed in the present study were between soccer and judo. Participation in these sports include high mechanical stimulus which may justify these results. According the position statement from American College of Sports Medicine (2004) (10), soccer is a ball sport and requires considerable osteogenic movements, such as running, acceleration and deceleration, jumping, changes of directions and lower leg impacts when touching and shooting the ball (25). The results of the present study show that these weight-bearing movements appear to be beneficial not only for lower limbs aBMD where the initial loading is applied, but also for the whole body aBMD.

These findings might be explained by the combined components included as part of the training routine of these soccer players (26). In addition, judo is a martial art which includes high frequency of different muscle contractions (eccentric, concentric and isometric), as well as body rotations, physical contact with the opponent and frequent falls on the ground (27) and these characteristics support the beneficial impact of this sport modality on bone health of whole body aBMD. In contrast, swimming was the sport that presented the lowest whole-body 
1 BMD, indicating that the absence of ground reaction forces during swimming training might

2 not be beneficial for whole body aBMD (28). The latter is recently supported by a systematic

3 review that included 64 studies across different ages and found that swimming participation

4 does not induce beneficial effects on different skeletal sites compared to controls (28).

The BMAD estimation allows the volumetric expression of aBMD by decreasing the risk of overestimating participants with high stature and the risk of underestimating those with short stature (13). Interestingly, the findings of the present study indicate that the gymnastics presented the highest BMAD values among the groups, which was followed by soccer and track \& field. Considering that gymnasts had the second shortest stature among the groups, the results of the present study removed the size bias and reinforces the importance of height adjustment when comparing bone variables in children derived from DXA outcomes as previously supported (29). In contrast, swimmers consistently were found to have significantly lower BMAD values compared to most groups, which strengthens the hypothesis that adolescents engaged in non-impact sport tend to have lower bone density, independently of the body size. Although BMAD analysis is not a new method in the paediatric bone field, studies involving this technique and comparing sport modalities in adolescents are scarce in the literature. It is of our knowledge only one study in the literature, by Dyson et al. (14), that observed that female gymnasts had higher BMAD at the whole body, femur neck and lumbar spine compared to the control group, which corroborates our findings. However, there is no evidence on other sports, which highlights the novelty of the evidence provided in the present study.

\section{Lumbar Spine aBMD}

At the spine aBMD, all groups presented similar values except the swimming group which had significantly lower lumbar spine aBMD compared to judo, volleyball and soccer. 
1 The lumbar spine skeletal site receives tension in the bone matrix during most of the human

2 stand position actions, and this tension is increased during participation in sports that involve

3 rotation of the core body segment. However, the core movements of the body do not differ

4 considerably among sports which may justify the similarity between the groups. In contrast,

5 during participation in judo, volleyball and soccer there is a high weight-bearing load (jumps,

6 running, fast short movements, changes of directions and falls on the ground) applied to the

7 core body part and therefore lumbar spine which might improve this skeletal site $(8,30,31)$.

In contrast, swimming practice involves rotation of the core part of the body but due to

9 hypogravity in the water all the forces applied in the lumbar spine are horizontal and mainly

10 applied in upper limbs $(6,32)$ and therefore do not induce adaptations. Studies in the literature

11 corroborate our findings (28), such as the recent manuscript developed by Bellver et al. (2019)

12 with female young adult athletes, competitors of World Championships and Olympic Games.

13 In this study, swimmers showed lower BMD in lumbar spine than soccer and volleyball players

14 although it was similar to the control group (31), denoting that effects of sports participation

15 on bone health during adolescence remained similar in early adulthood.

Lower Limbs aBMD

In the analyses of the lower limbs aBMD, soccer players had the highest aBMD values

which were significantly higher compared to most groups studied (except with track \& field and gymnastics). Soccer is a sport modality in which the lower limbs are predominantly used as part of the movements needed to achieve a high-level performance. These specific performance outcomes, such as running, jumping, changes of direction, acceleration and braking, and many small impacts of touching and shooting the ball (25) have high osteogenic potential to induce bone adaptations. Previous cross-sectional and longitudinal studies found that soccer practice induces positive adaptations to improve bone formation and consequently 
$1 \operatorname{aBMD}(3,8)$. These previous findings are in line with the results of the present study. Similarly,

2 some previous studies also have found that swimmers have similar or lower bone outcomes in

3 lower limbs even compared to the control group (3, 8). During swimming practice, the lower

4 limbs are used as stabilizer and float (32), which limits the muscular contractions and 5 consequently, the stress in the bone matrix.

6

7 Upper Limbs aBMD

At the upper limbs gymnastics had significantly higher aBMD values compared to all groups, except judo which presented the second highest aBMD. The female artistic gymnastics is a sport with high amount of movements involving tension, compression and torsion in the upper limbs. These movements performed during the practice involve jumps, muscular contractions and impulse forces. The arms are predominantly used during the vault and uneven bars apparatus movements which generate greater impact at the distal and proximal portions of the radius (33), increasing trabecular and cortical bone mineral density BMD mainly in the forearm (33). Besides that, a study by Helge \& Kanstrup (2002) (34) comparing rhythmic against artistic gymnasts observed significantly higher values of aBMD at the distal radius in artistic gymnastics athletes attributing these results to direct impact on the upper limbs during the practice, which might be the case for the findings observed in gymnasts of the present study. The higher aBMD values at the upper limbs in judo participants compared to karate, kung fu and swimming has been debated in the literature in a recent systematic review (30) and the results showed the judo as beneficial sport for site-specific BMD accrual in children and adolescents, including the upper limbs (30). Ito et al. (27) for example, found significantly higher aBMD for upper limbs in judokas compared to the control group and attributed these results to the movements performed during the practice of the modality and fall techniques. 
The differences observed in aBMD in this study between basketball and baseball might be explained by the movement patterns of baseball which involve direct and indirect impact with upper limbs, especially during pitches and rebound (35). Lastly, the upper limbs was the unique segment in which the swimmers did not present the lowest values, perhaps due to this body region concentrates all the propulsion force during the practice $(6,32)$, causing variations of muscular contractions and improve BMD (6).

\section{Soft tissues}

There is evidence in the literature that the body composition and muscular fitness affect the bone health, but the direction is not clear for fat mass (36). Besides that, Forero-Bogotá et al. (37) showed that a poor bone health is significantly related to low lean mass. Thus, understanding the impact of different sports on body composition is crucial for bone health during growth and to improve performance in specific sports.

The comparison of soft tissues showed that soccer, gymnastics and track \& field presented the lowest fat mass from the groups studied. Soccer is a sport with intermittent training patterns, and it includes aerobic and anaerobic components during practice. Considering that long distance running is the predominant part of the game (38), this could explain the low fat mass values for these soccer players. For instance, in a study by Seabra et al. (39) in which a 6-month soccer intervention on obese male adolescents proved effective for reducing body fat. Similarly, track \& field is a sport that involves up to 21 different disciplines and most of these disciplines require a high metabolic demand through two main energy pathways (aerobic and anaerobic) (40), justifying the low fat mass observed in this group.

In gymnastics, the specific physical characteristics in athletes are needed to allow the performance of technical moves and to succeed in the sport (41). Due to the high variability of the movements performed in gymnastics, athletes with a genetic predisposition of short stature, 
1 lower body mass and low fat mass have increased chances to perform the exercises well and

2 therefore are continuing to participate in the sport (39).

The lean soft tissue was higher in soccer compared to the most other groups in the present study. In general, sports with the highest values of aBMD at most skeletal sites had also the highest lean mass and lowest body fat mass in the present study, mainly soccer. Lean mass is the strongest predictor of bone density at different skeletal sites (whole body, lumbar

7 spine, lower limbs and upper limbs) in athletes (42) and therefore is crucial to understand the differences between the different sports practiced during adolescence. Although there are no studies comparing the lean soft tissue of a large number of sports practiced during adolescence, the literature has also shown that soccer players have higher lean soft tissue compared to other sports (such as swimming, karate and judo) (8) and control group (31). This result can be explained by the fact that soccer involves a large amount of muscle contractions (predominantly in the lower limbs) mainly in the control of the ball and maintain balance (38), in addition to training performed out of game with the aim of improving neuromuscular adaptations and muscle hypertrophy (38).

Additionally, each sport has distinct training characteristics, including training volume. Recent literature has shown that increased training volume results in changes of body composition and increase of BMD in adolescents soccer players (22). For this reason, the present study adjusted for weekly training load, allowing the comparisons between the sports to be more homogeneous and to understand the direct relation of sport and bone density.

Strengths and limitations

The literature was scarce in studies involving adolescents practicing a high number of different loading sports and this is the first study to compare 10 different sports, some of which for the first time, and a control group. The strengths of this study include the large sample size 
1 and the inclusion of many sports which allowed us to categorize the sports according to bone

2 density and soft tissue profiles. The present study controlled for the important covariates of sex, PHV, lean soft tissue, fat mass and weekly training volume (22-24) as these variables have a strong relationship with bone mass and development which indicates the strong internal validity of the results presented.

However, it is important to highlight that the cross-sectional results cannot make any causational inferences about sport participation. The findings can only show the cross-sectional status and the differences of bone and soft tissues between the sports compared. To analyse the effects of growth and maturation alongside the possible training effect, longitudinal studies are needed to indicate the long-term effect of each sport on bone and soft tissue profiles in comparison to a control group without the causality limitations of cross-sectional studies. However, there is a limited number of longitudinal studies conducted, with smaller number of sports groups compared and number of participants included (3, 43, 44). Randomized controlled trial studies are lacking because most children and adolescents are already engaged in different sports and activities which makes difficult the allocation to specific training hours of a single sport. Besides that, the method of estimating age of PHV might have an estimation error, due to the range of the chronological age of the groups included, which are outside the optimal band of estimation (1 year after/before the peak). For this reason, to minimise the estimation error the results were adjusted by the categorical variables of PHV (Pre-PHV, AtPHV and Post-PHV) (21), however, future studies are encouraged to consider recruiting participants from narrower age ranges preferably close to the PHV. Moreover, the sample size did not allow for sex specific comparisons and for this reason the analyses have been adjusted by sex. Finally, the genetic predisposition of different bone density and soft tissues could not be controlled. 
1

2

Lastly, the study did not control habitual physical activity in which might affect bone density and soft tissues, but previous evidence indicates that the sport specific training components are stronger predictors of bone density over and above the contribution of physical activity (42), beyond the lack of control of resistance training practice which can affect the bone mineral accrual.

\section{Conclusion}

In summary, soccer and gymnastics groups had the highest BMAD and aBMD at most skeletal sites. In contrast, swimming had the lowest aBMD at most skeletal sites. The soft tissue findings indicated that soccer had the highest lean soft tissue while volleyball, baseball and karate had the lowest lean soft tissue. Finally, baseball and volleyball groups had the highest fat mass, while soccer and gymnastics had the lowest fat mass. This study provides new collective findings about the bone and soft tissue profiles of ten different sports practiced during adolescence and categorize the sports according to highest and lowest values.

\section{Acknowledgments}

The authors gratefully acknowledge São Paulo Research Foundation (FAPESP), Coordenação de Aperfeicoamento de Pessoal de Nível Superior- Brasil (CAPES), Conselho Nacional de Desenvolvimento Científico e Tecnológico (CNPq) and the effort of participants and their parents and coaches. The authors also thank all researchers of Laboratory of InVestigation in Exercise (LIVE) for their support in data collection.

This study was supported by the São Paulo Research Foundation-FAPESP (FAPESP Process 2013/06963-5, 2015/13543-8, 2016/06920-2, 2017/09182-5, 2018/24164-6 and 2015/197103). Pedro Henrique Narciso received a Grant from the FAPESP (2018/21935-1); Santiago 
1 Maillane-Vanegas received a grant from the FAPESP (2016/20354-0); André Oliveira

2 Werneck received a Grant from the FAPESP (2017/27234-2).

3

\section{Conflict of Interest}

5 The authors declare that they have no competing interests.

6 The authors declare that the results of this study are presented clearly, honestly, and without

7 fabrication, falsification or inappropriate data manipulation. Besides that, the results of this

8 study do not constitute endorsement by the American College of Sports Medicine.

9 Author contributions: RRA collected the data (including DXA scans) and drafted the 10 manuscript. RAF designed the study, coordinated the data collection and critically reviewed 11 the manuscript and approved the final version. PHN and SMV contributed to the acquisition 12 of data and critically reviewed the manuscript and approved the final version. AOW 13 contributed to the acquisition of data, statistical expertise and critically reviewed the

14 manuscript and approved the final version. DV designed the study, had the conceptual idea of 15 the study and planned the data analysis, interpretation and critically reviewed all parts of the 16 manuscript. 


\section{References}

2 1. Baxter-Jones ADG, Faulkner RA, Forwood MR, Mirwald RL, Bailey DA. Bone mineral accrual from 8 to 30 years of age: an estimation of peak bone mass. J Bone Miner Res. 2011;26(8):1729-39.

2. Mouratidou T, Vicente-Rodriguez G, Gracia-Marco L, et al. Associations of Dietary Calcium, Vitamin D, Milk Intakes, and 25-Hydroxyvitamin D With Bone Mass in Spanish Adolescents: The HELENA Study. J Clin Densitom. 2013;16:110-7.

3. Vlachopoulos D, Barker AR, Ubago-Guisado E, et al. The effect of 12-month participation in osteogenic and non-osteogenic sports on bone development in adolescent male athletes. The PRO-BONE study. J Sci Med Sport. 2018;21(4):404-9.

4. Rizzoli R, Bianchi ML, Garabédian M, McKay HA, Moreno LA. Maximizing bone mineral mass gain during growth for the prevention of fractures in the adolescents and the elderly. Bone. 2010;46(2):294-305.

5. Svedbom A, Ivergård M, Hernlund E, Rizzoli R, Kanis JA. Epidemiology and economic burden of osteoporosis in Switzerland. Arch Osteoporos. 2014;9(1):187.

6. Agostinete RR, Maillane-Vanegas S, Lynch KR, et al. The Impact of Training Load on Bone Mineral Density of Adolescent Swimmers: A Structural Equation Modeling Approach. Pediatr Exerc Sci. 2017;29(4):520-8.

7. Werneck AO, da Silva DRP, Fernandes RA, Ronque ERV, Coelho-E-Silva MJ, Cyrino ES. Sport Participation and Metabolic Risk During Adolescent Years: A Structured Equation Model. Int J Sports Med. 2018;39(9):674-81.

8. Maillane-Vanegas S, Agostinete RR, R Lynch K, et al. Bone Mineral Density and Sports Participation. [Internet]. J Clin Densitom. 2018; available from: http://www.ncbi.nlm.nih.gov/pubmed/30068490. doi:10.1016/j.jocd.2018.05.041. 
Month Jumping Intervention to Improve Bone Geometry in Adolescent Male Athletes. Med Sci Sports Exerc. 2018;50(12):2544-54.

10. Kohrt WM, Bloomfield SA, Little KD, Nelson ME, Yingling VR, American College of Sports Medicine. American College of Sports Medicine Position Stand: physical activity and bone health. Med Sci Sports Exerc. 2004;36(11):1985-96.

11. Nikander R, Kannus P, Rantalainen T, Uusi-Rasi K, Heinonen A, Sievänen H. Crosssectional geometry of weight-bearing tibia in female athletes subjected to different exercise loadings. Osteoporos Int. 2010;21(10):1687-94.

12. Carter DR, Bouxsein ML, Marcus R. New approaches for interpreting projected bone densitometry data. J Bone Miner Res. 1992;7(2):137-45.

13. Katzman DK, Bachrach LK, Carter DR, Marcus R. Clinical and anthropometric correlates of bone mineral acquisition in healthy adolescent girls. J Clin Endocrinol Metab. 1991;73(6):1332-9.

14. Dyson K, Blimkie CJ, Davison KS, Webber CE, Adachi JD. Gymnastic training and bone density in pre-adolescent females. Med Sci Sports Exerc. 1997;29(4):443-50.

15. Olmedillas H, González-Agüero A, Moreno LA, Casajús JA, Vicente-Rodríguez G. Bone related health status in adolescent cyclists. PLoS One. 2011;6(9):e24841.

16. Telford RM, Telford RD, Cochrane T, Cunningham RB, Olive LS, Davey R. The influence of sport club participation on physical activity, fitness and body fat during childhood and adolescence: The LOOK Longitudinal Study. J Sci Med Sport. 2016;19(5):400-6.

17. Wilkinson K, Vlachopoulos D, Klentrou P, et al. Soft tissues, areal bone mineral density and hip geometry estimates in active young boys: the PRO-BONE study. Eur $J$ Appl Physiol. 2017;117(4):833-42.

18. Vlachopoulos D, Barker AR, Williams CA, Knapp KM, Metcalf BS, Gracia-Marco L. 
Effect of a program of short bouts of exercise on bone health in adolescents involved in different sports: the PRO-BONE study protocol. BMC Public Health. 2015;15:361.

19. Vlachopoulos D, Barker AR, Ubago-Guisado E, Williams CA, Gracia-Marco L. The effect of a high-impact jumping intervention on bone mass, bone stiffness and fitness parameters in adolescent athletes. Arch Osteoporos. 2018;13(1):128.

20. Moore SA, McKay HA, Macdonald H, et al. Enhancing a somatic maturity prediction model. Med Sci Sports Exerc. 2015;47(8):1755-64.

21. Kozieł SM, Malina RM. Modified Maturity Offset Prediction Equations: Validation in Independent Longitudinal Samples of Boys and Girls. Sports Med. 2018;48(1):221-36.

22. Varley I, Hughes DC, Greeves JP, Fraser WD, Sale C. Increased Training Volume Improves Bone Density and Cortical Area in Adolescent Football Players. Int J Sports Med. 2017;38(5):341-6.

23. Ubago-Guisado E, Vlachopoulos D, Barker AR, Christoffersen T, Metcalf B, GraciaMarco L. Effect of maturational timing on bone health in male adolescent athletes engaged in different sports: The PRO-BONE study. J Sci Med Sport. 2019;22(3):2538.

24. El Hage RP, Courteix D, Benhamou C-L, Jacob C, Jaffré C. Relative importance of lean and fat mass on bone mineral density in a group of adolescent girls and boys. Eur J Appl Physiol. 2009;105(5):759-64.

25. Seabra A, Marques E, Brito J, et al. Muscle strength and soccer practice as major determinants of bone mineral density in adolescents. Joint Bone Spine. 2012;79(4):403-8.

26. Chatzinikolaou A, Michaloglou K, Avloniti A, et al. The Trainability of Adolescent Soccer Players to Brief Periodized Complex Training. Int J Sports Physiol Perform. 2018;13(5):645-55. 
1 27. Ito IH, Mantovani AM, Agostinete RR, et al. Practice of martial arts and bone mineral density in adolescents of both sexes. Rev Paul Pediatr (English Ed. 2016;34(2):210-5.

28. Gómez-Bruton A, Gónzalez-Agüero A, Gómez-Cabello A, Casajús JA, VicenteRodríguez G. Is Bone Tissue Really Affected by Swimming? A Systematic Review. PLoS One. 2013;8(8):e70119.

29. Zemel BS, Leonard MB, Kelly A, et al. Height adjustment in assessing dual energy xray absorptiometry measurements of bone mass and density in children. $J$ Clin Endocrinol Metab. 2010;95(3):1265-73.

30. Ciaccioni S, Condello G, Guidotti F, Capranica L. Effects of Judo Training on Bones: A Systematic Literature Review. J strength Cond Res. 2019;33(10):2882-96.

31. Bellver M, Del Rio L, Jovell E, Drobnic F, Trilla A. Bone mineral density and bone mineral content among female elite athletes. Bone. 2019;127:393-400.

32. Gourgoulis V, Boli A, Aggeloussis N, et al. The effect of leg kick on sprint front crawl swimming. J Sports Sci. 2014;32(3):278-89.

33. Jürimäe J, Gruodyte-Raciene R, Baxter-Jones ADG. Effects of Gymnastics Activities on Bone Accrual during Growth: A Systematic Review. J Sports Sci Med. 2018;17(2):245-58.

34. Helge EW, Kanstrup I-L. Bone density in female elite gymnasts: impact of muscle strength and sex hormones. Med Sci Sports Exerc. 2002;34(1):174-80.

35. Fleisig G, Chu Y, Weber A, Andrews J. Variability in baseball pitching biomechanics among various levels of competition. Sport Biomech. 2009;8(1):10-21.

36. Chaplais E, Thivel D, Greene D, et al. Bone-adiposity cross-talk: implications for pediatric obesity. A narrative review of literature. J Bone Miner Metab. 2015;33(6):592-602.

37. Forero-Bogotá MA, Ojeda-Pardo ML, García-Hermoso A, et al. Body Composition, 
Nutritional Profile and Muscular Fitness Affect Bone Health in a Sample of Schoolchildren from Colombia: The Fuprecol Study. Nutrients. 2017;9(2):106.

38. Stølen T, Chamari K, Castagna C, Wisløff U. Physiology of soccer: an update. Sports Med. 2005;35(6):501-36.

39. Seabra A, Katzmarzyk P, Carvalho MJ, et al. Effects of 6-month soccer and traditional physical activity programmes on body composition, cardiometabolic risk factors, inflammatory, oxidative stress markers and cardiorespiratory fitness in obese boys. $J$ Sports Sci. 2016;34(19):1822-9.

40. Zouhal H, Jabbour G, Jacob C, et al. Anaerobic and Aerobic Energy System Contribution to 400-m Flat and 400-m Hurdles Track Running. J Strength Cond Res. 2010;24(9):2309-15.

41. Sands, B., Caine, D. J., \& Borms J. Scientific aspects of women's gymnastics. 45th ed. Karger Medical and Scientific Publishers; 2003. 110-127 p.

42. Vlachopoulos D, Ubago-Guisado E, Barker AR, et al. Determinants of Bone Outcomes in Adolescent Athletes at Baseline: The PRO-BONE Study. Med Sci Sports Exerc. 2017;49(7):1389-96.

43. Ubago-Guisado E, Vlachopoulos D, Fatouros IG, et al. Longitudinal determinants of 12-month changes on bone health in adolescent male athletes. Arch Osteoporos. 2018;13(1):106.

44. Vlachopoulos D, Barker AR, Ubago-Guisado E, et al. Longitudinal Adaptations of Bone Mass, Geometry, and Metabolism in Adolescent Male Athletes: The PROBONE Study. J Bone Miner Res. 2017;32(11):2269-77. 
Table 1. Descriptive characteristics of the sample stratified by sports $(\mathrm{N}=625)$

\begin{tabular}{|c|c|c|c|c|c|c|c|c|c|c|c|}
\hline Descriptive characteristics & $\begin{array}{c}\text { Basketball } \\
\mathrm{n}=55 \\
\text { Mean } \\
(\mathrm{SD})\end{array}$ & $\begin{array}{l}\text { Soccer } \\
\mathrm{n}=100 \\
\text { Mean } \\
(\mathrm{SD})\end{array}$ & $\begin{array}{c}\text { Swimming } \\
n=67 \\
\text { Mean } \\
(\mathrm{SD})\end{array}$ & $\begin{array}{c}\text { Volleyball } \\
n=32 \\
\text { Mean } \\
(\mathrm{SD})\end{array}$ & $\begin{array}{c}\text { Karate } \\
\mathrm{n}=41 \\
\text { Mean } \\
(\mathrm{SD}) \\
\end{array}$ & $\begin{array}{c}\text { Judo } \\
\mathrm{n}=54 \\
\text { Mean } \\
\text { (SD) }\end{array}$ & $\begin{array}{c}\text { Kung Fu } \\
\text { n=39 } \\
\text { Mean } \\
\text { (SD) }\end{array}$ & $\begin{array}{c}\text { Baseball } \\
\mathrm{n}=22 \\
\text { Mean } \\
(\mathrm{SD})\end{array}$ & $\begin{array}{c}\text { Gymnastics } \\
\mathrm{n}=16 \\
\text { Mean } \\
\text { (SD } \\
\end{array}$ & $\begin{array}{c}\text { Track \& Field } \\
\mathrm{n}=27 \\
\text { Mean } \\
(\mathrm{SD})\end{array}$ & $\begin{array}{c}\text { Non- sport } \\
\mathrm{n}=172 \\
\text { Mean } \\
(\mathrm{SD})\end{array}$ \\
\hline Number of males/females & $55 / 0$ & $100 / 0$ & $45 / 22$ & $2 / 30$ & $20 / 21$ & $36 / 18$ & $29 / 10$ & $21 / 1$ & $0 / 16$ & $16 / 11$ & $117 / 55$ \\
\hline Chronological age (years) & $\begin{array}{l}13.8 \\
(1.3)\end{array}$ & $\begin{array}{l}15.0^{\mathrm{a}} \\
(1.8)\end{array}$ & $\begin{array}{l}13.2^{\mathrm{b}} \\
(1.8)\end{array}$ & $\begin{array}{c}15.0^{\mathrm{a}, \mathrm{c}} \\
(1.1)\end{array}$ & $\begin{array}{c}13.1^{\mathrm{b}, \mathrm{d}} \\
(1.8)\end{array}$ & $\begin{array}{c}13.1^{\mathrm{b}, \mathrm{d}} \\
(1.8)\end{array}$ & $\begin{array}{c}13.4^{\mathrm{b}, \mathrm{d}} \\
(1.7)\end{array}$ & $\begin{array}{c}12.1^{\mathrm{a}, \mathrm{b}, \mathrm{d}} \\
(1.6)\end{array}$ & $\begin{array}{l}13.6 \\
(1.7)\end{array}$ & $\begin{array}{c}15.6^{\mathrm{a}, \mathrm{c}, \mathrm{e}, \mathrm{f}, \mathrm{g}, \mathrm{h}, \mathrm{i}} \\
(1,8)\end{array}$ & $\begin{array}{c}14.5^{\mathrm{c}, \mathrm{e}, \mathrm{f}, \mathrm{g}, \mathrm{h}} \\
(2.3)\end{array}$ \\
\hline Body mass $(\mathrm{kg})$ & $\begin{array}{c}65.8 \\
(17.4)\end{array}$ & $\begin{array}{c}63.8 \\
(13.2)\end{array}$ & $\begin{array}{l}55.6^{\mathrm{a}, \mathrm{b}} \\
(13.2)\end{array}$ & $\begin{array}{c}59.1 \\
(10.8)\end{array}$ & $\begin{array}{l}50.4^{\mathrm{a}, \mathrm{b}} \\
(14.0)\end{array}$ & $\begin{array}{l}54.4^{\mathrm{a}, \mathrm{b}} \\
(13.7)\end{array}$ & $\begin{array}{c}57.8 \\
(12.9)\end{array}$ & $\begin{array}{l}51.1^{\mathrm{a}, \mathrm{b}} \\
(15.4)\end{array}$ & $\begin{array}{c}45.6^{\mathrm{a}, \mathrm{b}, \mathrm{c}, \mathrm{d}, \mathrm{f}, \mathrm{g}} \\
(7.7)\end{array}$ & $\begin{array}{c}62.6^{\mathrm{i}} \\
(17.1)\end{array}$ & $\begin{array}{c}55.8^{\mathrm{a}, \mathrm{b}, \mathrm{i}} \\
(14.4)\end{array}$ \\
\hline Height $(\mathrm{cm})$ & $\begin{array}{l}176.3 \\
(10.3)\end{array}$ & $\begin{array}{l}173.3 \\
(10.6)\end{array}$ & $\begin{array}{c}163.3^{a, b} \\
(10.5)\end{array}$ & $\begin{array}{c}165.6^{a, b} \\
(6.6)\end{array}$ & $\begin{array}{c}157.5^{\mathrm{a}, \mathrm{b}, \mathrm{d}} \\
(11.0)\end{array}$ & $\begin{array}{c}157.7^{\mathrm{a}, \mathrm{b}, \mathrm{d}} \\
(12.0)\end{array}$ & $\begin{array}{c}162.5^{a, b} \\
(10.4)\end{array}$ & $\begin{array}{c}153.0^{\mathrm{a}, \mathrm{b}, \mathrm{c}, \mathrm{d}} \\
(12.1)\end{array}$ & $\begin{array}{c}156.2^{\mathrm{a}, \mathrm{b}, \mathrm{d}} \\
(8.2)\end{array}$ & $\begin{array}{c}171.9^{\mathrm{ce,f}, \mathrm{f}, \mathrm{g}, \mathrm{h}, \mathrm{i}} \\
(10.3)\end{array}$ & $\begin{array}{c}163.3^{\mathrm{a}, \mathrm{b}, \mathrm{h}, \mathrm{j}} \\
(11.5)\end{array}$ \\
\hline Age from PHV (years) & $\begin{array}{c}0.8 \\
(1.2)\end{array}$ & $\begin{array}{c}1.4 \\
(1.5)\end{array}$ & $\begin{array}{l}0.4^{\mathrm{b}} \\
(1.5)\end{array}$ & $\begin{array}{c}2.7^{a, b, c} \\
(1.1)\end{array}$ & $\begin{array}{l}0.3^{\text {b.d }} \\
(1.7)\end{array}$ & $\begin{array}{l}0.0^{\text {b.d }} \\
(1.7)\end{array}$ & $\begin{array}{l}0.4^{\mathrm{b}, \mathrm{d}} \\
(1.7)\end{array}$ & $\begin{array}{c}-1.2^{\mathrm{a}, \mathrm{b}, \mathrm{c}, \mathrm{d}, \mathrm{e}, \mathrm{e}, \mathrm{g}} \\
(1.3)\end{array}$ & $\begin{array}{l}1.3^{\mathrm{d}, \mathrm{h}} \\
(1.5)\end{array}$ & $\begin{array}{c}2.4^{\mathrm{a}, \mathrm{c}, \mathrm{e}, \mathrm{f}, \mathrm{g}, \mathrm{h}} \\
(1.6)\end{array}$ & $\begin{array}{c}1.1^{\mathrm{d}, \mathrm{f}, \mathrm{h}, \mathrm{j}} \\
(1.9)\end{array}$ \\
\hline Lean soft tissue $(\mathrm{kg})$ & $\begin{array}{l}49.5 \\
(9.1)\end{array}$ & $\begin{array}{c}52.5 \\
(10.4)\end{array}$ & $\begin{array}{c}40.7^{\mathrm{a}, \mathrm{b}} \\
(9.6)\end{array}$ & $\begin{array}{c}36.1^{\mathrm{a}, \mathrm{b}} \\
(4.9)\end{array}$ & $\begin{array}{c}35.2^{\mathrm{a}, \mathrm{b}} \\
(7.9)\end{array}$ & $\begin{array}{l}36.3^{\mathrm{a}, \mathrm{b}} \\
(10.4)\end{array}$ & $\begin{array}{c}38.8^{\mathrm{a}, \mathrm{b}} \\
(9.0)\end{array}$ & $\begin{array}{c}34.1^{\mathrm{a}, \mathrm{b}} \\
(7.7)\end{array}$ & $\begin{array}{c}32.5^{\mathrm{a}, \mathrm{b}, \mathrm{c}, \mathrm{g}} \\
(5.3)\end{array}$ & $\begin{array}{c}49.5^{\mathrm{de}, \mathrm{e}, \mathrm{g}, \mathrm{h}, \mathrm{i}} \\
(13.0)\end{array}$ & $\begin{array}{c}38.4^{\mathrm{a}, \mathrm{b}, \mathrm{i}, \mathrm{j}} \\
(9.6)\end{array}$ \\
\hline Fat mass $(\mathrm{kg})$ & $\begin{array}{c}12.6 \\
(12.0)\end{array}$ & $\begin{array}{c}7.9 \\
(3.5)\end{array}$ & $\begin{array}{l}11.8^{\mathrm{b}} \\
(7.7)\end{array}$ & $\begin{array}{c}20.1^{\mathrm{a}, \mathrm{b}, \mathrm{c}} \\
(9.1)\end{array}$ & $\begin{array}{l}12.0^{\mathrm{d}} \\
(8.2)\end{array}$ & $\begin{array}{l}14.0^{\mathrm{b}} \\
(8.1)\end{array}$ & $\begin{array}{c}15.6^{\mathrm{b}} \\
(10.4)\end{array}$ & $\begin{array}{c}13.9 \\
(10.1)\end{array}$ & $\begin{array}{l}9.3^{\mathrm{d}, \mathrm{g}} \\
(3.9)\end{array}$ & $\begin{array}{l}9.5^{\mathrm{d}} \\
(7.5)\end{array}$ & $\begin{array}{c}13.8^{\mathrm{b}, \mathrm{d}, \mathrm{i}} \\
(9.5)\end{array}$ \\
\hline $\begin{array}{l}\text { Training parameters: } \\
\text { Days per week }\end{array}$ & $\begin{array}{c}4.4 \\
(1.5)\end{array}$ & $\begin{array}{c}4.7 \\
(1.0)\end{array}$ & $\begin{array}{l}5.8^{\mathrm{a}, \mathrm{b}} \\
(0.7)\end{array}$ & $\begin{array}{c}2.9^{\mathrm{a}, \mathrm{b}, \mathrm{c}} \\
(1.2)\end{array}$ & $\begin{array}{c}4.1^{b, c, d} \\
(0.9)\end{array}$ & $\begin{array}{c}3.1^{\mathrm{a}, \mathrm{b}, \mathrm{c}, \mathrm{e}} \\
(0.5)\end{array}$ & $\begin{array}{l}2.5^{\mathrm{a}, \mathrm{b}, \mathrm{c}, \mathrm{e}, \mathrm{f}} \\
(0.9)\end{array}$ & $\begin{array}{c}3.7^{\mathrm{b}, \mathrm{c}, \mathrm{g}} \\
(1.1)\end{array}$ & $\begin{array}{c}3.0^{\mathrm{a}, \mathrm{b}, \mathrm{c}, \mathrm{e}} \\
(0.9)\end{array}$ & $\begin{array}{c}5.6^{\mathrm{a}, \mathrm{b}, \mathrm{d}, \mathrm{e}, \mathrm{f}, \mathrm{g}, \mathrm{h}, \mathrm{i}} \\
(0.7)\end{array}$ & -- \\
\hline $\begin{array}{l}\text { Time per day } \\
\text { (minutes) }\end{array}$ & $\begin{array}{l}182.9 \\
(45.0)\end{array}$ & $\begin{array}{l}163.3 \\
(31.5)\end{array}$ & $\begin{array}{l}164.0 \\
(33.7)\end{array}$ & $\begin{array}{l}121.9^{\mathrm{a}, \mathrm{b}, \mathrm{c}} \\
(28.4)\end{array}$ & $\begin{array}{l}139.0^{\mathrm{a}} \\
(56.4)\end{array}$ & $\begin{array}{l}104.2^{\mathrm{a}, \mathrm{b}, \mathrm{c}, \mathrm{e}} \\
(40.9)\end{array}$ & $\begin{array}{c}106.4^{\mathrm{a}, \mathrm{b}, \mathrm{c}} \\
(41.5)\end{array}$ & $\begin{array}{l}191.4^{\mathrm{d}, \mathrm{e}, \mathrm{f}, \mathrm{g}} \\
(58.8)\end{array}$ & $\begin{array}{l}206.3^{\mathrm{b}, \mathrm{c}, \mathrm{d}, \mathrm{e}, \mathrm{f}, \mathrm{g}} \\
\quad(48.8)\end{array}$ & $\begin{array}{c}161.1^{\mathrm{d}, \mathrm{f,g}} \\
(40.9)\end{array}$ & -- \\
\hline $\begin{array}{l}\text { Training volume } \\
\text { (minutes per week) }\end{array}$ & $\begin{array}{c}836.6 \\
(364.1) \\
\end{array}$ & $\begin{array}{c}775.5 \\
(225.6) \\
\end{array}$ & $\begin{array}{l}947.0^{\mathrm{b}} \\
(245.3)\end{array}$ & $\begin{array}{c}373.1^{\mathrm{a}, \mathrm{b}, \mathrm{c}} \\
(207.8)\end{array}$ & $\begin{array}{c}559.0^{\mathrm{a}, \mathrm{b}, \mathrm{c}, \mathrm{d}} \\
(230.1)\end{array}$ & $\begin{array}{c}339.7^{\mathrm{a}, \mathrm{b}, \mathrm{c}, \mathrm{e}} \\
(239.0)\end{array}$ & $\begin{array}{c}262.1^{\mathrm{a}, \mathrm{b}, \mathrm{c}, \mathrm{e}} \\
(156.1)\end{array}$ & $\begin{array}{c}716.8^{\mathrm{c}, \mathrm{d}, \mathrm{f}, \mathrm{g}} \\
(275.4)\end{array}$ & $\begin{array}{c}626.3^{\mathrm{c}, \mathrm{d}, \mathrm{f}, \mathrm{g}} \\
(259.7)\end{array}$ & $\begin{array}{l}914.4^{\mathrm{d}, \mathrm{e}, \mathrm{f}, \mathrm{g}, \mathrm{i}} \\
(277.1)\end{array}$ & -- \\
\hline
\end{tabular}

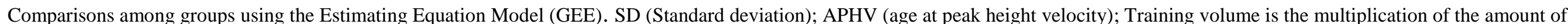

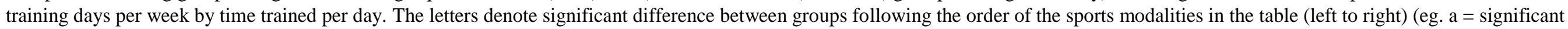
difference compared to the first sport modality in the table [basketball], $b=$ difference compared to second sport modality in the table [soccer]; $\mathrm{p}<0.05$ ). 
Table 2. Descriptive bone characteristics of the sample (without adjust by confounders) $(\mathrm{N}=625)$.

\begin{tabular}{|c|c|c|c|c|c|c|c|c|c|c|c|}
\hline & $\begin{array}{c}\text { Basketball } \\
\mathrm{n}=56\end{array}$ & $\begin{array}{l}\text { Soccer } \\
n=100\end{array}$ & $\begin{array}{c}\text { Swimming } \\
\mathrm{n}=67\end{array}$ & $\begin{array}{c}\text { Volleyball } \\
n=32\end{array}$ & $\begin{array}{c}\text { Karate } \\
n=41\end{array}$ & $\begin{array}{l}\text { Judo } \\
\mathrm{n}=54\end{array}$ & $\begin{array}{c}\text { Kung Fu } \\
n=39\end{array}$ & $\begin{array}{c}\text { Baseball } \\
n=22\end{array}$ & $\begin{array}{c}\text { Gymnastics } \\
n=16\end{array}$ & $\begin{array}{c}\text { Track \& Field } \\
n=27\end{array}$ & $\begin{array}{c}\text { Non- sport } \\
n=172\end{array}$ \\
\hline & $\begin{array}{r}\text { Mean } \\
(\mathrm{SD})\end{array}$ & $\begin{array}{l}\text { Mean } \\
(\mathrm{SD})\end{array}$ & $\begin{array}{r}\text { Mean } \\
(\mathrm{SD})\end{array}$ & $\begin{array}{r}\text { Mean } \\
(\mathrm{SD})\end{array}$ & $\begin{array}{l}\text { Mean } \\
(\mathrm{SD})\end{array}$ & $\begin{array}{l}\text { Mean } \\
(\mathrm{SD})\end{array}$ & $\begin{array}{l}\text { Mean } \\
(\mathrm{SD})\end{array}$ & $\begin{array}{c}\text { Mean } \\
(\mathrm{SD}\end{array}$ & $\begin{array}{l}\text { Mean } \\
(\mathrm{SD})\end{array}$ & $\begin{array}{l}\text { Mean } \\
(\mathrm{SD})\end{array}$ & $\begin{array}{r}\text { Mean } \\
(\mathrm{SD})\end{array}$ \\
\hline Number of males/females & $55 / 0$ & $100 / 0$ & $45 / 22$ & $2 / 30$ & $20 / 21$ & $36 / 18$ & $29 / 10$ & $21 / 1$ & $0 / 16$ & $16 / 11$ & $117 / 55$ \\
\hline \multicolumn{12}{|l|}{ aBMD $\left(\mathrm{g} / \mathrm{cm}^{2}\right)$} \\
\hline DXA- Upper limbs & $\begin{array}{c}0.821 \\
(0.111)\end{array}$ & $\begin{array}{l}0.880^{\mathrm{a}} \\
(0.148)\end{array}$ & $\begin{array}{l}0.775^{\mathrm{b}} \\
(0.105)\end{array}$ & $\begin{array}{l}0.802^{\mathrm{b}} \\
(0.087)\end{array}$ & $\begin{array}{c}0.731^{\mathrm{a}, \mathrm{b}, \mathrm{d}} \\
(0.090)\end{array}$ & $\begin{array}{l}0.800^{\mathrm{b}, \mathrm{e}} \\
(0.166)\end{array}$ & $\begin{array}{l}0.760^{\mathrm{b}} \\
(0.081)\end{array}$ & $\begin{array}{l}0.725^{\mathrm{a}, \mathrm{b}} \\
(0.090)\end{array}$ & $\begin{array}{c}0.802 \\
(0.089)\end{array}$ & $\begin{array}{c}0.884^{\mathrm{c}, \mathrm{e}, \mathrm{g}, \mathrm{h}} \\
(0.141)\end{array}$ & $\begin{array}{l}0.773^{\mathrm{b}, \mathrm{j}} \\
(0.117)\end{array}$ \\
\hline DXA- Lower limbs & $\begin{array}{c}1.340 \\
(0.165)\end{array}$ & $\begin{array}{l}1.446^{\mathrm{a}} \\
(0.177)\end{array}$ & $\begin{array}{l}1.134^{\mathrm{a}, \mathrm{b}} \\
(0.132)\end{array}$ & $\begin{array}{c}1.238^{\mathrm{a}, \mathrm{b}, \mathrm{c}} \\
(0.106)\end{array}$ & $\begin{array}{l}1.170^{\mathrm{a}, \mathrm{b}} \\
(0.152)\end{array}$ & $\begin{array}{l}1.172^{\mathrm{a}, \mathrm{b}} \\
(0.165)\end{array}$ & $\begin{array}{l}1.163^{\mathrm{a}, \mathrm{b}} \\
(0.119)\end{array}$ & $\begin{array}{c}1.103^{\mathrm{a}, \mathrm{b}, \mathrm{d}} \\
(0.149)\end{array}$ & $\begin{array}{l}1.182^{\mathrm{a}, \mathrm{b}} \\
(0.124)\end{array}$ & $\begin{array}{c}1.386^{\mathrm{c}, \mathrm{d}, \mathrm{e}, \mathrm{f}, \mathrm{g}, \mathrm{h}, \mathrm{i}} \\
(0.200)\end{array}$ & $\begin{array}{c}1.185^{\mathrm{a}, \mathrm{b}, \mathrm{j}} \\
(0.162)\end{array}$ \\
\hline DXA- Spine & $\begin{array}{c}1.065 \\
(0.157)\end{array}$ & $\begin{array}{c}1.108 \\
(0.166)\end{array}$ & $\begin{array}{l}0.977^{\mathrm{b}} \\
(0.139)\end{array}$ & $\begin{array}{l}1.151^{\mathrm{c}} \\
(0.134)\end{array}$ & $\begin{array}{c}0.982^{\mathrm{b}, \mathrm{d}} \\
(0.160)\end{array}$ & $\begin{array}{l}0.996^{\mathrm{b}, \mathrm{d}} \\
(0.158)\end{array}$ & $\begin{array}{c}0.971^{\mathrm{b}, \mathrm{d}} \\
(0.154)\end{array}$ & $\begin{array}{c}0.888^{\mathrm{ab}, \mathrm{d}} \\
(0.132)\end{array}$ & $\begin{array}{c}1.040 \\
(0.160)\end{array}$ & $\begin{array}{c}1.123^{\mathrm{ce}, \mathrm{g}, \mathrm{h}} \\
(0.169)\end{array}$ & $\begin{array}{c}1.002^{\mathrm{b}, \mathrm{d}, \mathrm{h}, \mathrm{j}} \\
(0.172)\end{array}$ \\
\hline DXA- Whole body-LH & $\begin{array}{l}1.095 \\
(0.23)\end{array}$ & $\begin{array}{l}1.180^{\mathrm{a}} \\
(0.141)\end{array}$ & $\begin{array}{l}0.965^{\mathrm{a}, \mathrm{b}} \\
(0.108)\end{array}$ & $\begin{array}{l}1.052^{\mathrm{b}, \mathrm{c}} \\
(0.089)\end{array}$ & $\begin{array}{c}0.974^{\mathrm{a}, \mathrm{b}} \\
(0.116)\end{array}$ & $\begin{array}{c}0.995^{\mathrm{a}, \mathrm{b}} \\
(0.141)\end{array}$ & $\begin{array}{c}0.980^{\mathrm{a}, \mathrm{b}} \\
(0.097)\end{array}$ & $\begin{array}{c}0.927^{\mathrm{a}, \mathrm{b}, \mathrm{d}} \\
(0.116)\end{array}$ & $\begin{array}{l}0.997^{\mathrm{b}} \\
(0.102)\end{array}$ & $\begin{array}{c}1.139^{\mathrm{ce,ef}, \mathrm{g}, \mathrm{h}, \mathrm{i}} \\
(0.155)\end{array}$ & $\begin{array}{c}0.994^{\mathrm{a}, \mathrm{b}, \mathrm{j}} \\
(0.126)\end{array}$ \\
\hline BMAD $\left(\mathrm{g} / \mathrm{cm}^{3}\right)$ & $\begin{array}{c}0.090 \\
(0.006)\end{array}$ & $\begin{array}{l}0.095^{\mathrm{a}} \\
(0.006)\end{array}$ & $\begin{array}{l}0.088^{\mathrm{a}, \mathrm{b}} \\
(0.005)\end{array}$ & $\begin{array}{l}0.088^{b} \\
(0.005)\end{array}$ & $\begin{array}{l}0.090^{\mathrm{b}, \mathrm{c}} \\
(0.006)\end{array}$ & $\begin{array}{l}0.089^{b, c} \\
(0.006)\end{array}$ & $\begin{array}{l}0.087^{b} \\
(0.005)\end{array}$ & $\begin{array}{l}0.088^{\mathrm{b}} \\
(0.005)\end{array}$ & $\begin{array}{l}0.094^{\mathrm{c}, \mathrm{d}} \\
(0.006)\end{array}$ & $\begin{array}{c}0.095^{\mathrm{c}, \mathrm{d}, \mathrm{fg}, \mathrm{h}} \\
(0.006)\end{array}$ & $\begin{array}{c}0.089^{b, c, i, j} \\
(0.007)\end{array}$ \\
\hline
\end{tabular}

Comparisons among groups using the Estimating Equation Model (GEE). SD (standard deviation); DXA (Dual-energy X-ray absorptiometry); Whole body-LH (whole body less head); BMAD (bone mineral apparent density). The letters denote significant difference between groups following the order of the sports modalities in the table (left to right) (eg. $a=$ significant difference compared to the first sport modality in the table [basketball], $\mathrm{b}=$ difference compared to second sport modality in the table [soccer]; $\mathrm{p}<0.05$ ) 
A

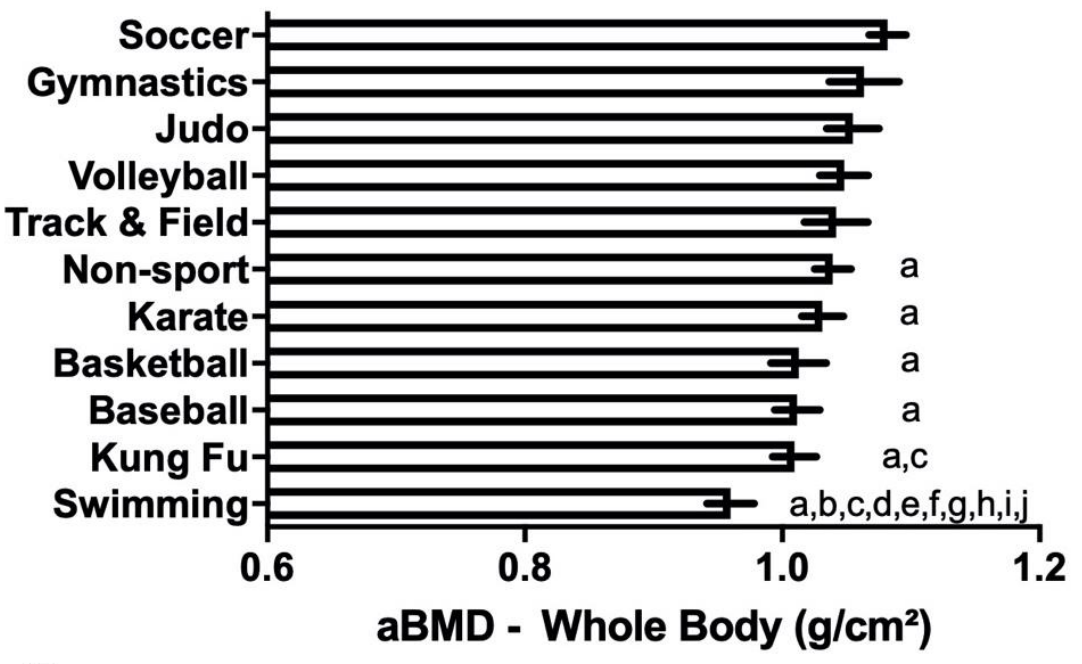

C

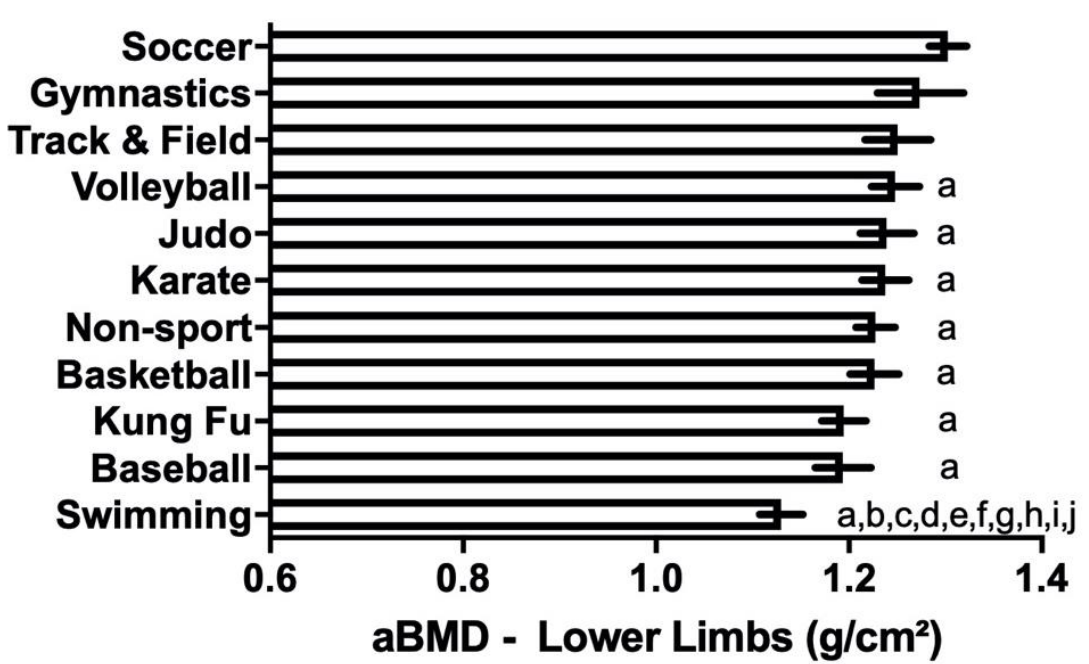

B

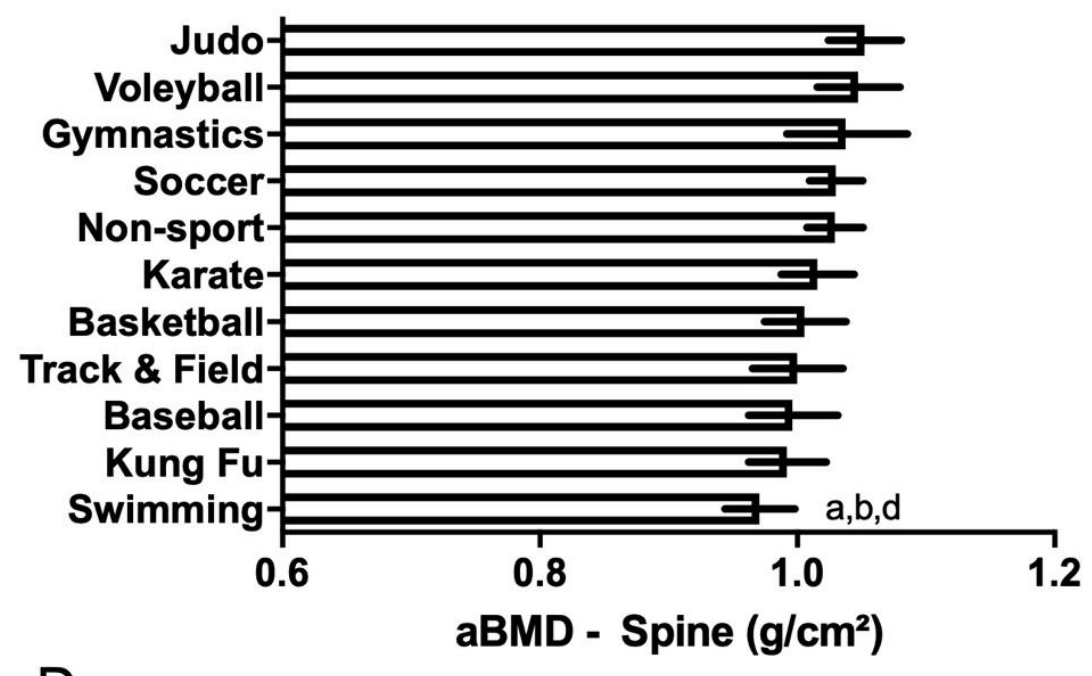

D

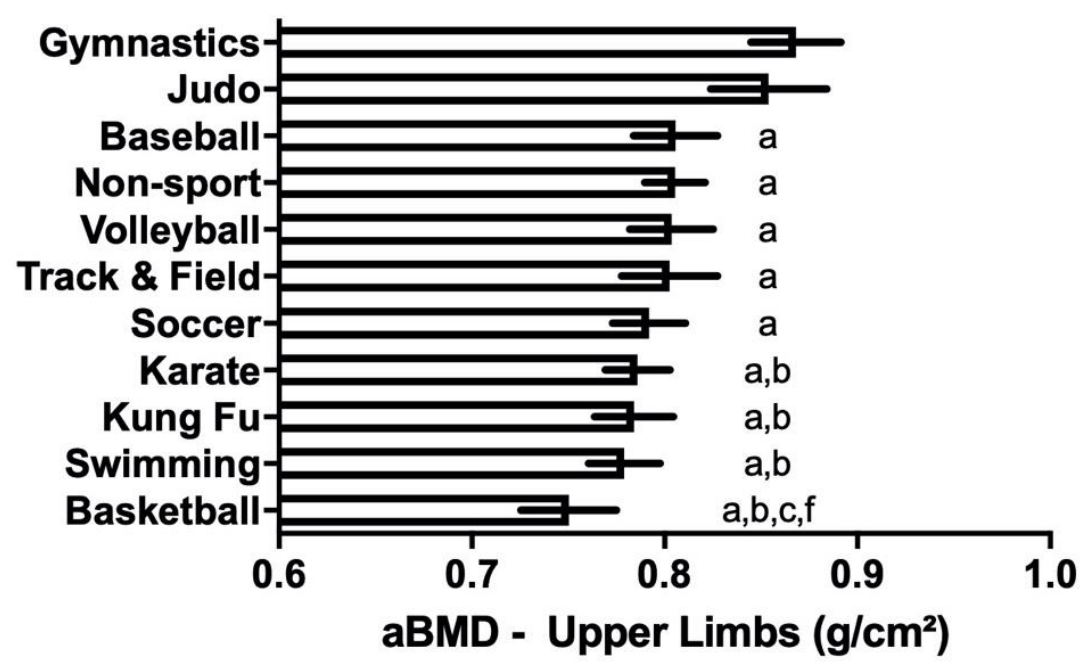

Figure 1. Comparisons of BMD $\left(\mathrm{g} / \mathrm{cm}^{2}\right)$ among 10 sports and non-sport group categorized hierarchically (from highest to lowest) using the Estimating Equation Model (GEE) adjusted by sex, PHV status, lean soft tissue, fat mass and weekly training volume. The letters denote significant lower values between groups following hierarchical order (eg. a $=$ significant lower values compared to the first sport modality, $b=$ difference compared to second sport modality; $p<0.05)$. 


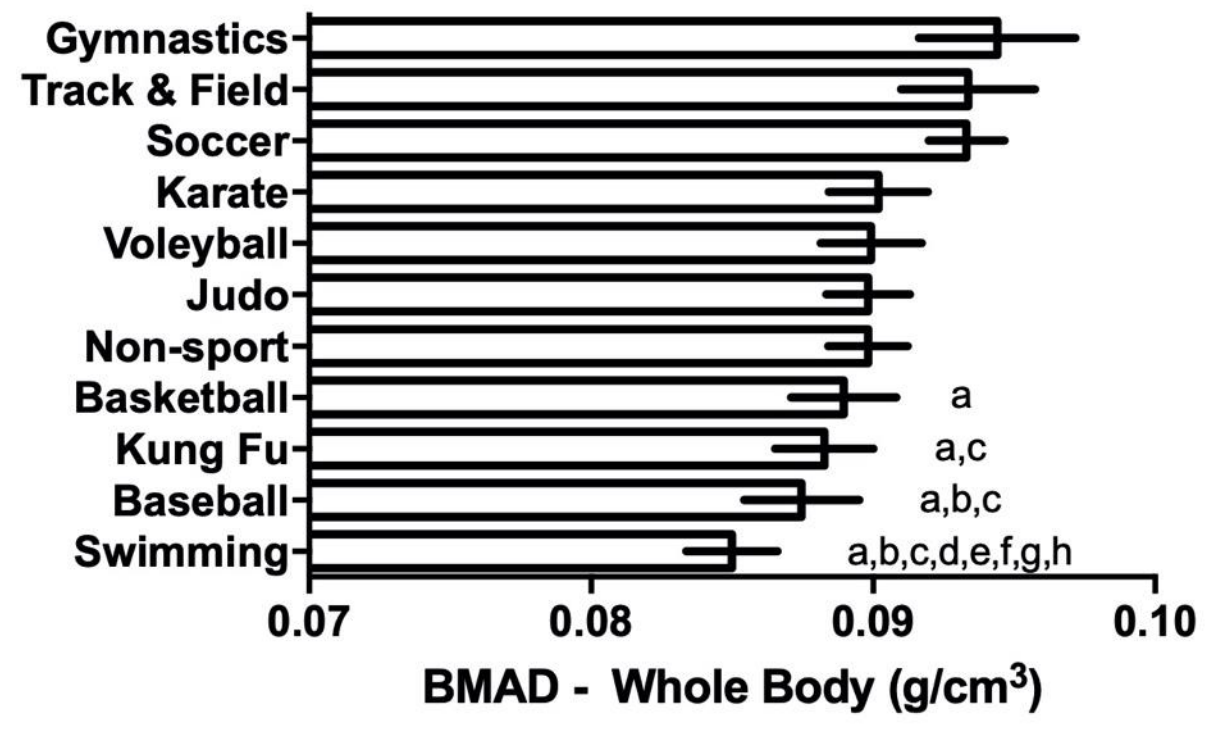

Figure 2. Comparisons of Bone Mineral Apparent Density (BMAD) $\left(\mathrm{g} / \mathrm{cm}^{3}\right)$ among 10 sports and non-sport group categorized hierarchically (from highest to lowest) using the Estimating Equation Model (GEE) adjusted by sex, PHV status, lean soft tissue, fat mass and weekly training volume. The letters denote significant lower values between groups following hierarchical order (eg. a = significant lower values compared to the first sport modality, $\mathrm{b}=$ difference compared to second sport modality; $\mathrm{p}<0.05)$. 


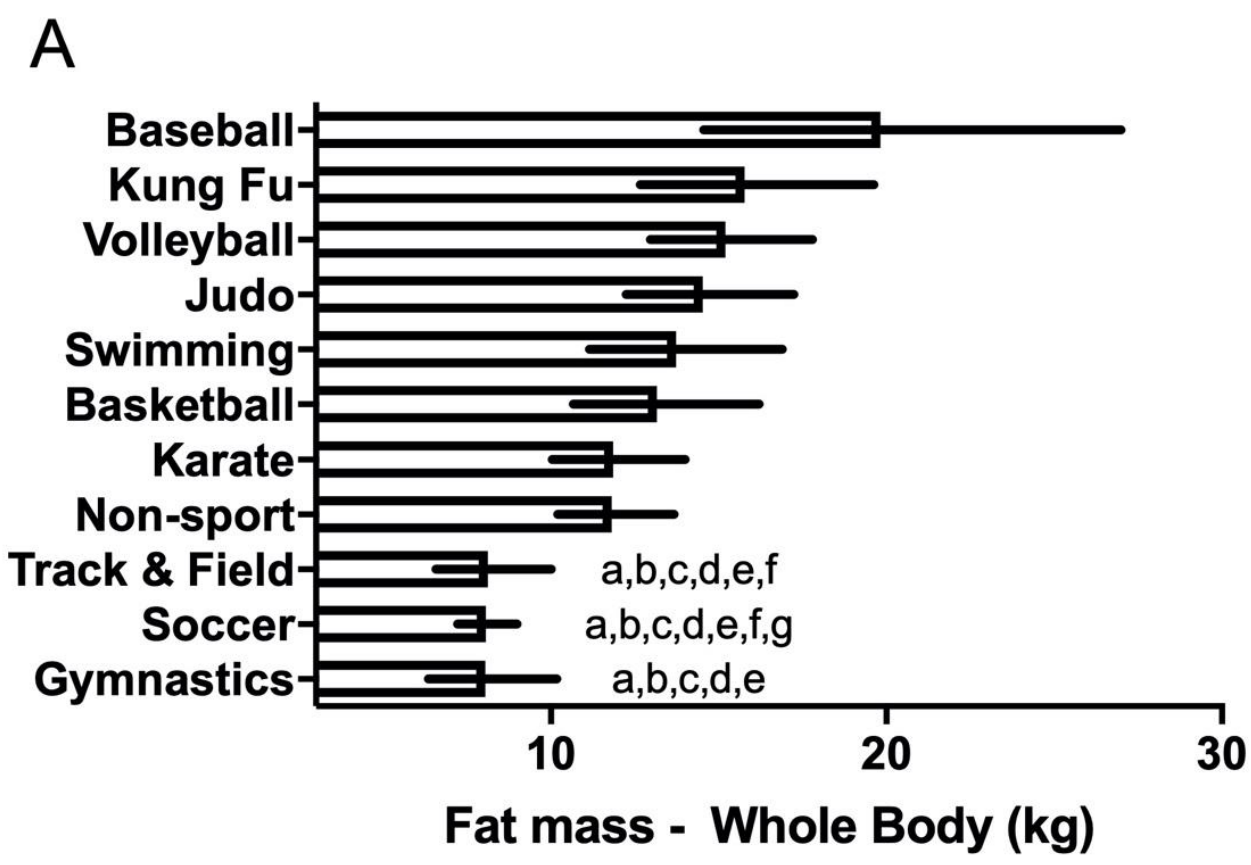

B

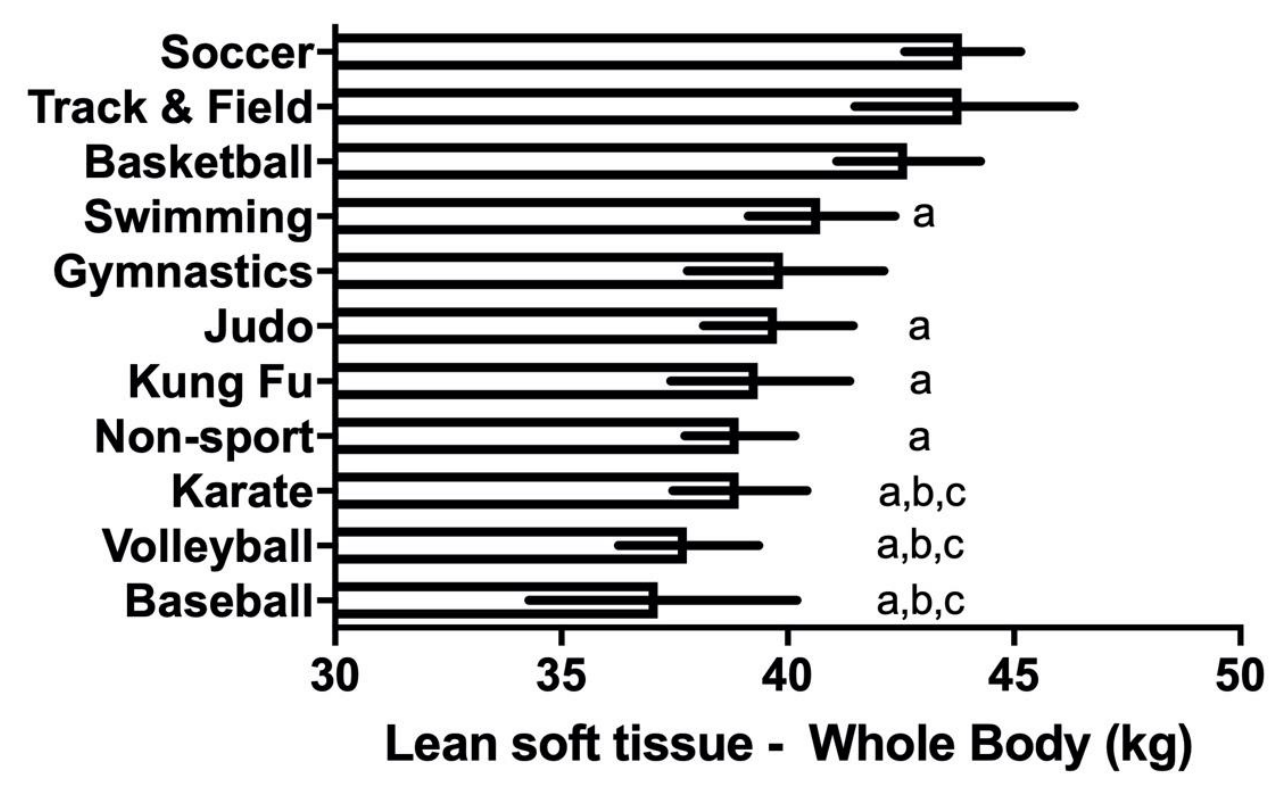

Figure 3. Comparisons of soft tissues $(\mathrm{kg})$ among 10 sports and non-sport group categorized hierarchically (from highest to lowest) using the Estimating Equation Model (GEE). The results adjusted by sex, PHV status, weekly training volume and lean soft tissue (A), and the results were adjusted by sex, PHV status, weekly training volume and fat mass (B). The letters denote significant lower values between groups following hierarchical order (eg. $\mathrm{a}=$ significant lower values compared to the first sport modality, $b=$ difference compared to second sport modality; $\mathrm{p}<0.05$ ). 